\title{
Integrative cancer informatics for the identification of prognostic and predictive biomarkers
}

lgor Jurisica

\section{From São Paulo Advanced School of Comparative Oncology} Águas de São Pedro, Brazil. 30 September - 6 October 2012

Cancer development is a multi-step process that leads to uncontrolled tumor cell growth. Multiple pathways are involved; typically some signalling and regulatory pathways are activated, while others are suppressed. Systematically exploring these networks of proteins will lead to better understanding of disease initiation and progression. Integrating these data with microRNA regulatory networks may identify control mechanism that these master regulators use to affect oncogenesis. Including data on drug targets, modes of actions predicted from drug profiles and compound similarity will in turn lead to more effective patient treatment. To address these challenges, we developed a system for an integrative analysis, prediction and characterization of molecular signatures and relevant protein-protein interactions, microRNA: gene interactions, and resources for rationally identifying drug combinations for cancer treatment.

\section{Competing interests}

There are no competing interests in this presentation.

Published: 4 April 2013

\section{doi:10.1186/1753-6561-7-S2-K7}

Cite this article as: Jurisica: Integrative cancer informatics for the identification of prognostic and predictive biomarkers. BMC Proceedings 2013 7(Suppl 2):K7.
Correspondence: juris@ai.utoronto.ca

Ontario Cancer Institute and University Health Network, University of Toronto, Canada
Submit your next manuscript to BioMed Central and take full advantage of:

- Convenient online submission

- Thorough peer review

- No space constraints or color figure charges

- Immediate publication on acceptance

- Inclusion in PubMed, CAS, Scopus and Google Scholar

- Research which is freely available for redistribution

\section{() Biomed Central}

